\title{
Research evolution in banking performance: a bibliometric analysis
}

\author{
S. M. Shamsul Alam, Mohammad Abdul Matin Chowdhury* (iD and Dzuljastri Bin Abdul Razak
}

\begin{abstract}
Banking performance has been regarded as a crucial factor of economic growth. Banks collect deposits from surplus and provide loans to the investors that contribute to the total economic growth. Recent development in the banking industry is channelling the funds and participating in economic activities directly. Hence, academic researchers are gradually showing their concern on banking performance and its effect on economic growth. Therefore, this study aims to explore the academic researchers on this particular academic research article. By extracting data from the web of Science online database, this study employed the bibliometrix package (biblioshiny) in the ' $R$ ' and VOSviewer tool to conduct performance and science mapping analyses. A total of 1308 research documents were analysed, and 36 documents were critically reviewed. The findings exhibited a recent growth in academic publications. Three major themes are mainly identified, efficiency measurement, corporate governance effect and impact on economic growth. Besides, the content analysis represents the most common analysis techniques used in the past studies, namely DEA and GMM. The findings of this study will be beneficial to both bank managers and owners to gauge a better understanding of banking performance. Meanwhile, academic researchers and students may find the findings and suggestions to study in the banking area.
\end{abstract}

Keywords: Banking performance, Banking efficiency, Bibliometric analysis, Web of Science, Biblioshiny, VOSviewer, Content analysis

\section{Introduction}

The financial services formed a significant contributory trademark in the overall economic growth by stimulating employment, offering vast avenues for investment and services to the consumers and the society [1]. Thus, economic development is led by economic growth whereby required capital is provided by the financial services [2]. Suggestively, capital creation by the financial services industry through accumulation and mobilisation of resources is considered the most crucial economic growth strategy component [3]. The banking system associates with creating funds by accumulating funds from surplus and channelling them to the investors as credit; those exhibit excellent ideas to generate a surplus

*Correspondence: matinchy@outlook.com

Department of Finance, International Islamic University Malaysia, Jalan Gombak, 53100 Kuala Lumpur, Malaysia in the economy but lack the capital to implement such ideas $[4,5]$. Accordingly, the banking system plays a vital role to pledge the leading role of finance in economic development and promoting stable and healthy financial and economic development [6].

Banking performance has been regarded as a crucial factor of economic growth [7]. Efficiency and productivity change measures are rapidly used to evaluate banking performance. Academic researchers have been focusing on the efficiency and productivity of banking institutions for a long period, while economic growth is carried out in the discussions. Discovering research activities on banking efficiency and productivity in economic growth enables researchers to identify the local and international input to this particular discipline. More so, it will enable researchers to identify the 'hot spots' discussed by academic researchers and find the research gaps [8]. Indeed, banking performance in standings is a broad 
scientific topic, and estimating research activities might not be useful. For instance, research activities in this area extended to several constituents such as methodological approaches, banking approaches. In the current study, banking efficiency and productivity are considered as banking performance that contributes to the economic growth of an economy. Therefore, the main objective of this study is to explore the research activities of banking performance to economic growth. The investigation of banking performance research activities will enable the researchers to find the present directions of the research area and thus speculates the future research suggestions. Besides, it will also enable to expound the depth of past research activities and themes on banking performance relating to the economic growth measurements.

The use of the bibliometric method is appropriate to demonstrate the research shape and activity, volume and growth in a specific discipline [9]. A bibliometric method is a quantitative application of bibliometric data [10]. It analyses a wide-ranging quantity of published research articles employing the statistical tool to identify trends and citations or/and co-citations of a certain theme by year, author, country, journal, theory, method, and research constituent [11]. Significantly, this technique further distinguishes key research themes and active researchers, countries and institutions for future research planning and funding [12]. Scholars apply this method for several reasons: to reveal emerging trends in published research articles and journal performance, cooperation patterns, and research elements, and to reconnoitre the intellectual edifice of an exact domain in the existing literature $[9,13]$.

Minimal studies have used bibliometric analysis related to banks. For instance, Violeta and Gordana have employed bibliometric analysis to spot the trends of DEA application in banking [14]. Another study conducted by Ikra et al. applied the bibliometric method to Islamic banking efficiency [15]. By an extensive search on the Scopus, Web of Science and Google Scholar, no such study was found related to bibliometric analysis on banking performance to the economic growth. Nevertheless, this study will be the first attempt to conduct bibliometric methods on the banking performance to the economic growth that could be the basis for future studies.

The findings of this study unfolded several contributions to both policymakers, bank managers and academic researchers. Firstly, the findings would benefit the policymakers regarding the contribution and trends of banking performance. It would allow them to take necessary initiatives to promote and improve banking performance, thus economic development. Meanwhile, bank managers may utilise the findings to strengthen their banking operations by acknowledging key factors that contributed to the performance. Finally, academic researchers are enabled to detect the current trend and topics related to the banking area that leads to further studies.

\section{Methods}

Bibliometric analysis has achieved enormous popularity in social sciences research in the current years [9, 1618]. The popularity of bibliometric analysis is observed from the development, accessibility and availability of software, for instance, Leximancer, Gephi, VOSviewer, Biblioshiny and publication databases (Web of Science and Scopus). Further, the rapid growth of bibliometric analysis in scientific production has emerged from business research to information science [9]. The popularity of bibliometric methodology in social science research is not a trend but moderately an image of its usefulness for constructing high research impact by handling excessive scientific data [9].

The bibliometric analysis is beneficial for briefing the trends in the research documents classifying 'blind spots' and 'hot spots', and finding a more inclusive understanding of the published research documents [19]. In detail, this analysis empowers the recognition of the most advanced (hot spots) and the less established topics (blind spots) within the documents that, shared with other bibliometric procedures, recommend future research avenues. The bibliometric analysis uncovers several ascriptions, such as unveiling emerging trends in documents and the performance of journals, research constituents and collaboration patterns and discovering the intellectual edifice of an exact domain in the existing literature $[13,18]$. The data that apply in this analysis incline to be immense (hundreds, thousands) and unbiased in nature (publications and citations number, keywords occurrences and topics). However, its explanations often depend on both subjective (thematic analysis) and objective (performance analysis) assessments formed through well-versed techniques and procedures [9]. Therefore, this study applied bibliometric analysis to examine the general perspective on banking performance and economic growth.

Two categories are mainly manifest in the bibliometric techniques, namely, performance and science mapping. Precisely, research elements' contributions are accounted for in the performance analysis, while the connections between research elements are focused on science mapping [9]. This study follows performance analysis, science mapping and network analysis suggested by Donthu et al. [9].

\section{Data extraction process}

Two primary databases, the Web of Science and the Scopus, are commonly used in the bibliometric analysis [20]. 
Both databases are prominent for the peer-reviewed published research articles. The data for this analysis were a collection of bibliographic data from the Web of Science. The Web of Science (WoS) is a multidisciplinary online database providing access to several citation databases, namely Science Citation Index Expanded (SCIE), Social Sciences Citation Index (SSCI), Emerging Sources Citation Index (ESCI), Arts and Humanities Citation Index (AHCI), Conference Proceedings Citation Index, Index Chemicus and Current Chemical Reactions [18, 21].

This study has applied a two-stage data extraction process, following Bretas and Alon, Alon et al. and Apriliyanti and Alon [16, 22, 23] as shown in Fig. 1. The choice of the keywords is crucial to ensure that it covers the total body of published documents on banking performance and economic growth [21]. Accordingly, the selection of keywords was carried out by reviewing several abstracts and authors' keywords in most related literature on the Web of Science. The selected keywords were executed in the WoS online database on 9 August 2021. A combination of keyword search terms was considered; (1) 'banking performance*' to nail all discrepancies of the term such as the role of the bank, bank efficiency, bank productivity, banking efficiency, banking productivity, banking performance, bank performance, upon refining the search by including only research articles from the categories; economics, business finance, business, management, operations research management, social sciences mathematical measures and documents written in English.
The second stage extracted raw data from the online database combined, checked for duplicate documents and merged using ' $R$ '. Further, the documents were filtered in the 'biblioshiny' tool to omit book chapters and conference proceedings. After the extraction process for the bibliometric analysis, several impactful documents were selected based on local and global citations to conduct content analysis. The content analysis allowed the researcher to identify the leading research scopes and trends. Further, it allows identifying the streams and recommendations for future studies [22]. A total of 36 documents were selected to conduct a comprehensive review and valuation of the documents.

\section{Results}

\section{Performance analysis}

Performance analysis investigates the contributions of academic research elements to a particular discipline [24]. This analysis is naturally descriptive, which is the hallmark of bibliometric analysis [9]. It is a standard method in reviews to exhibit the performance of various research elements such as authors, countries, institutions and sources similar to the profile or background of respondents generally presented in empirical studies, albeit more statistically $[9,18]$. Many measures exist in the performance analysis; hence, the most protuberant measurements are publications number and citations per research constituent or year. The publication is considered productivity, whereby citation measures influence an impact [9]. Besides, citation per document and

\section{Selection of key topic \\ (Bank performance/efficiency) \\ Online database \\ (The Web of Science)}

Input search terms (Titles, keywords, abstract)

("bank efficiency" OR "bank productivity" OR "banking efficiency" OR "banking productivity" OR "banking performance" OR "bank performance" OR "banking growth"

OR "bank growth")

Results: 1973 documents

Refine:

Document types: articles

Subject categories: Economics, Business Finance, Business, management, Operations

Research Management; Social Sciences Mathematical measures

Language: English

Refined results: 1447 documents

Extracted: bibtex format

Filtered documents in "Biblioshiny' package

Total data for analysis: 1308

Fig. 1 Data extraction process 
$h$-index associate both publications and citations with evaluating research performance [18].

Table 1 presents the publication's performance of banking performance. The results show a total number of 1308 documents published from 1972 to the present. Among 2275 contributed authors, a total of 202 authors were solely, and 2106 authors collaborated to the publications. A total of 31,458 citations received by published documents lead to an average of 629.16 citations per year, while 775 in $h$-index and 1023 in $g$-index. Hence, the banking efficiency field acknowledged productivity of research published by an average of 26.16 documents per year whereby nearly two authors $(\mathrm{CI}=1.9)$ published one article, and standardised collaboration is 0.43 (between 0 and 1).

The annual production of scientific publications on banking efficiency is presented in Fig. 2. The first research article related to banking performance was published by Fraser and Rose [25], who studied the effect of new bank appearance in the market on bank performance. The annual growth of publications on banking performance or banking efficiency is recorded to $12.39 \%$. The publications are significantly increasing in recent periods, especially from 2016 to the present. However, the mandated growth in publications is observed between 2004 and 2015, while earlier periods (1972-2003) were quite

Table 1 Metrics for performance analysis

\begin{tabular}{|c|c|c|}
\hline Metric & Description & Result \\
\hline Total publications (TP) & Number of total publications & 1308 \\
\hline Number of contributing authors (NCA) & Total of number of contributed authors & 2275 \\
\hline Single-authored documents (SA) & Number of single-authored publications & 202 \\
\hline Co-authored documents (CA) & Number of co-authored publications & 2106 \\
\hline Number of active years of publication (NAY) & Total periods of publications by research area & 50 years \\
\hline Productivity per active year of publication (PAY) & Total publications/number of active years of publication (TP/NAY) & 26.16 \\
\hline Total citations (TC) & Total citations received by published articles & 31,458 \\
\hline Average citations (AC)/year & Average citations per year of publications & 629.16 \\
\hline Collaboration index (Cl) & The extent of collaboration $\{(\mathrm{NCA} / \mathrm{TP}) / \mathrm{TP}\}$ & 1.9 \\
\hline Collaboration coefficient (CC) & Standardises the extent of researcher collaboration between 0 and $1\{1-(T P / N C A)\}$ & 0.43 \\
\hline$h$-index $(h)$ & $h$ Number of documents cited at least $h$ times (a measure of influence) & 775 \\
\hline$g$-index (g) & $g$ Number of documents cited at least $g^{2}$ times (a measure of impact) & 1023 \\
\hline
\end{tabular}

\section{PUBLICATIONS TREND OF BANK PERFORMANCE}

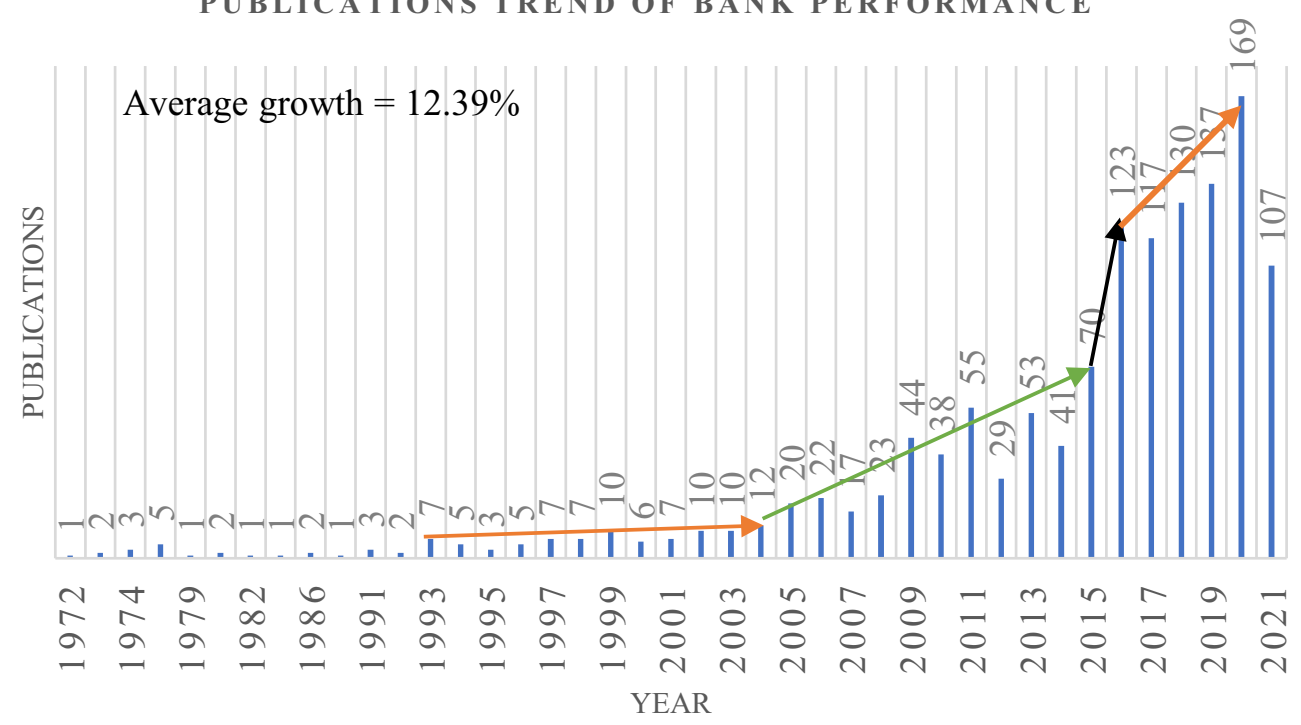

Fig. 2 Annual Scientific production 
sluggish. In these consequences, academic researchers have started to focus on banking performance or banking efficiency in the recent period. As a result, it can be concluded that banking performance and its sphere are shaping upwards through the research contributions.

\section{Science mapping}

Science mapping investigates the connections between research elements [26] that relates to the intellectual connections and structural networks within research constituents [9]. The science mapping includes citation analysis, bibliographic coupling, co-citation analysis, cooccurrence network, collaboration techniques. When combined with network analysis, these techniques are instrumental in exhibiting the research area's bibliometric edifice and intellectual structure [27].

\section{Citation analysis}

The citation analysis is a fundamental approach for science mapping that runs on the assumption that citations reproduce intellectual contributions and impact the research horizons [28]. This analysis shows the impact of published documents by measuring the number of citations they received [9]. Accordingly, it enables the discovery of the most influential and informative documents in a research constituent. Thus, it allows gathering insights into that constituent's intellectual dynamics [9]. Table 2 presents the top 20 impactful and influential documents in the field of banking performance or efficiency. The analysis has discovered that a total of 1112 documents (85\%) out of 1308 documents received global citations. The global citations refer to the number of citations received in the overall Web of Science citations. However, 196 documents (about 15\%) have not received any citation; meanwhile, 130 documents (about $10 \%)$ received only one citation. A document written by Berger An received the highest number (665) of citations which was published in 1997. The second most influential document was written by Seiford [51] received a total of 549 citations, followed by the document written by Back (2013) received 512 citations. In fact, a total of four documents written by Berger An rank in the top 20 impactful research articles in the field of banking performance or efficiency.

Factually, the majority of the documents without citations was published in a recent period. At the same time, the highly cited documents were published quite earlier. To detect the immediate influence of more recent documents is to apply the measurement of an average citation per year [29]. By evaluating the average citations per year, nine out of ten documents are also among the top 10 documents. Perpetually, Beck [45] holds the highest number of average citations per year (56.89), followed
Table 2 Top 20 most cited papers. Source: Biblioshiny R package

\begin{tabular}{lll}
\hline Document & Total Citations & TC per Year \\
\hline Berger An (1997), J Bank Financ & 665 & 26.60 \\
Seiford Lm (1999), Manage Scienc & 549 & 23.87 \\
BeckT (2013), J Bank Finance & 512 & 56.89 \\
Beltratti A (2012), J Financ Econ & 484 & 48.40 \\
Berger An (2013), J Financ Econ & 463 & 51.44 \\
Bonin Jp (2005), J Bank Financ & 451 & 26.53 \\
Berger An (2009), J Bank Financ & 438 & 33.69 \\
Fahlenbrach R (2011), J Financ Econ & 390 & 35.45 \\
De Andres P (2008), J Bank Financ & 359 & 25.64 \\
Aebi V (2012), J Bank Financ & 303 & 30.30 \\
Mester Lj (1996), J Bank Financ & 286 & 11.00 \\
Ariss Rt (2010), J Bank Financ & 274 & 22.83 \\
BeckT (2010), J Financ & 272 & 22.67 \\
Micco A (2007), J Bank Financ & 268 & 17.87 \\
Hermes N (2011) World Dev & 263 & 23.91 \\
Berger An (1993), J Bank Financ & 253 & 8.72 \\
Fiordelisi F (2011), J Bank Financ & 252 & 22.91 \\
Casu B (2003), Appl Econ & 236 & 12.42 \\
Garcia-Herrero A (2009), J Bank Financ & 228 & 17.54 \\
Lin X (2009), J Bank Financ & 225 & 17.31 \\
\hline
\end{tabular}

by Berger An (2013) ranked second position (51.44) and Beltratti A (2012) ranked the following position (48.40). Based on the citation analysis, it can be elucidated that Berger An is the most influential author in the banking efficiency research constituent.

\section{Co-occurrence analysis}

Co-occurrence analysis was projected by Callon et al. [30], considered as content analysis that is useful in plotting the strength of connotation within keywords in textual data. In other words, co-occurrence analysis is an approach that investigates the actual content of the document itself [9]. It maps the pertinent literature straight from the associations of keywords shared by research articles [24, 27, 31, 32]. The co-occurrence analysis deduces words to appear recurrently in a cluster. It exhibits conceptual or semantic groups of various topics or sub-topics considered by research constituents $[9,24]$. Cobo and Herrera signified that spotted clusters could be applied with few objectives [24]. For instance, they can be applied to analyse their progression by gauging extension across successive subperiods and measuring the research area through performance analysis. Figure 3 displays the co-occurrence of keywords within the bank efficiency research constituent. As the focus of this research, bank performance represents the larger node associated with corporate governance, financial performance, financial crisis, nonperforming loans and others. In these 


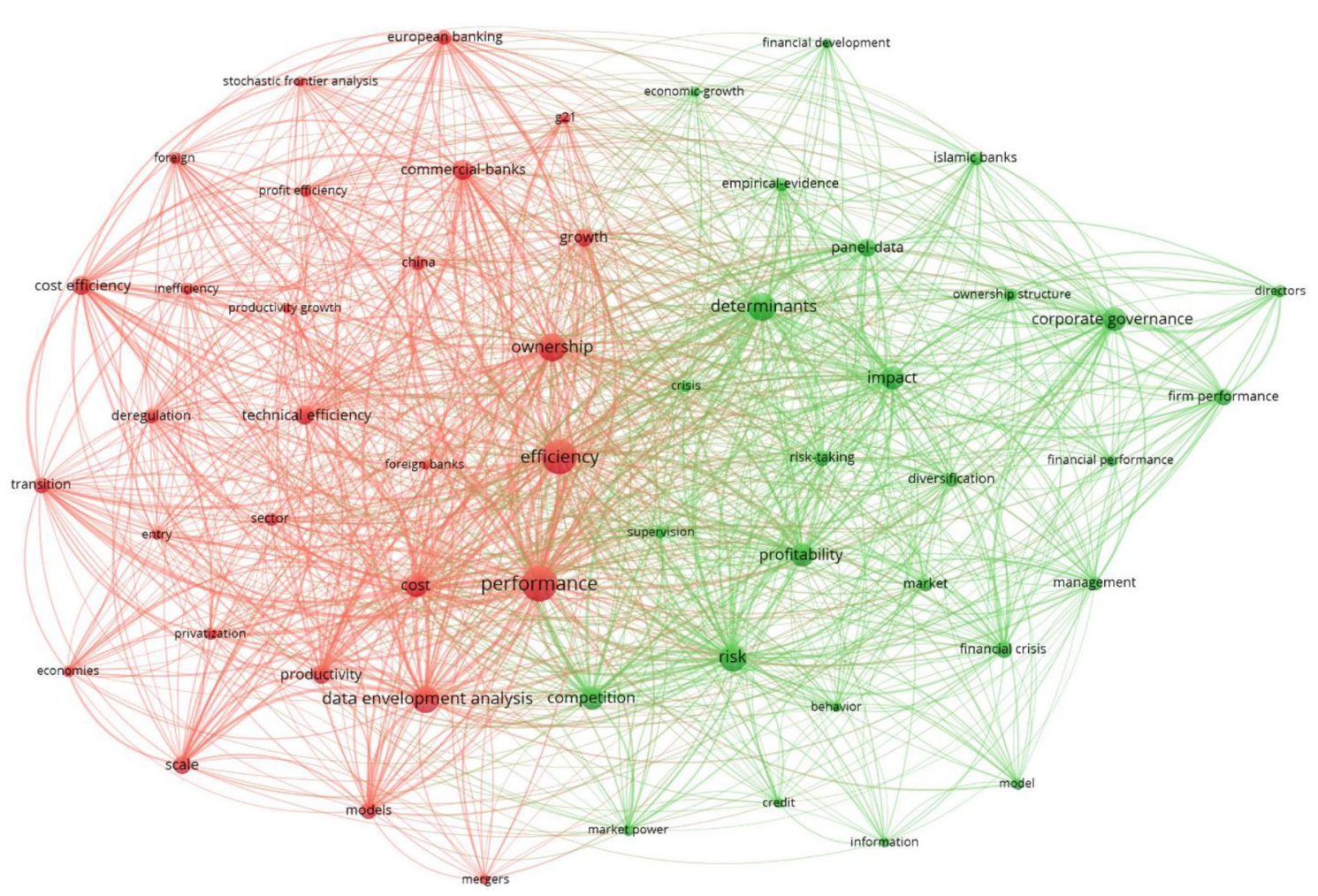

Fig. 3 Co-occurrence of keywords, Tool:VOSviewer. Note the nodes represent the keywords, and the edges between words present their occurrence of interactions. Each colour of nodes represents a cluster/theme. The size of the node presents a greater frequency of occurrence

scenarios, the red-coloured cluster depicts that these subtopics or variables are directly associated related to the bank performance theme due to repetitive cooccurrence of those words. Likewise, the green-coloured cluster represents a theme related to bank efficiency associated with performance and ownership. In the same cluster, the nonparametric data envelopment analysis is extensively used to measure commercial banks' technical and cost efficiency and productivity. Parametric stochastic frontier analysis is narrowly observed in efficiency measurements comparably. The green-coloured cluster depicts the determinants of bank profitability including other impactful variables such as risk, competition, corporate governance. This cluster applied panel data in order to examine performance, financial development as well as economic growth. Each of the cluster identifies the interacted themes used in the published documents using co-occurrence of keywords.

\section{Collaboration networks}

Collaboration analysis explores the associations within researchers in a particular constituent. It is a formal way of intellectual association among researchers [33,
34]. Therefore, it is crucial to understand how researchers associate among themselves [9]. In the presence of growing theoretical and methodological complexity in research, intellectual networking (collaboration) has become commonplace [33]. Indeed, collaboration or interaction among researchers enables improvements in academic research; for instance, greater interactions among diverse researchers allow richer insights and greater clarity [35]. Researchers who collaborate form a network named 'invisible collages' whose research can help improve undertakings in the study field [36]. Figure 4 presents the collaboration network of authors those co-authored academic articles in banking efficiency. Based on the collaboration network, Wanke P (Universidade Federal do Rio de Janeiro) was the most collaborated author who co-authored with four authors from different institutions in different countries. At the same time, Matousek, R (University Kent), Hasan, I (Rensselaer Polytechnic Institute) and Mamatzakis, E (University of Sussex), have also exhibited as greater collaborative researchers. In these consequences, authors from different institutions and from different parts of the world are collaborating to the banking performance/efficiency field. 


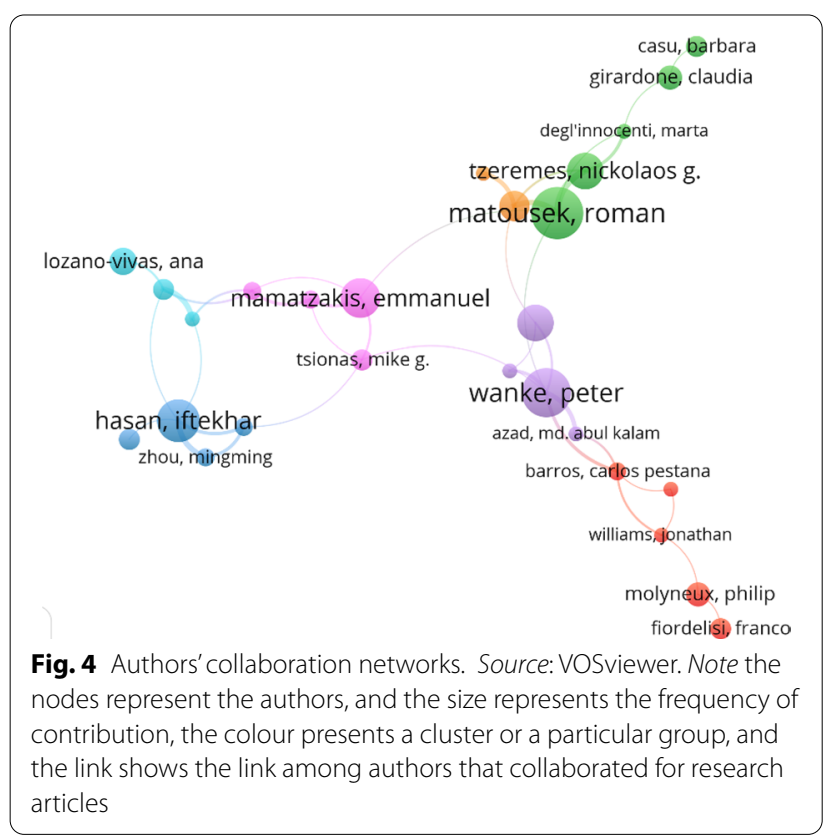

\section{Bibliographic coupling}

Co-authorship or collaborative networks within the authors and other crucial facets in the collaboration networks are the collaboration of author-affiliated countries and institutions [31]. Figure 5 exhibits the collaboration network within authors' affiliated organisations. University Malaya and University Utara Malaysia, University Malaya and University Putra Malaysia, University Malaya and University Fed Rio de Janeiro all depict a strong collaboration network. In general, all the institutions display an embellishment among the institutions within the same region.

Similar to co-authors' affiliated institutions, the collaboration of authors' country presents a steady association among authors' connections that allow exploring comparative and concurrent research works. Figure 6 represents the network of collaborative authors' affiliation countries. These countries include South Africa and the USA, England and the USA, Australia and the USA, Malaysia and the USA, Germany and the USA, representing a high proportion of authors' affiliated institutions are in the USA with this country performing as a hub of coauthorship publications from 1972 to 2021.

\section{Discussion}

This study discusses trending themes based on the bibliometric findings and reviews of highly cited and most recent documents (see Appendix 1). It also indicated the type of study, theories, methods and main findings to suggest comprehensive future studies.

\section{Research directions}

Between 1991 and 2010, studies related to banking performance have posited several antecedents to banking performance. Figure 7 displays the trend topics based on author keywords that appeared between 1972 and 2010. Studies in this period mainly focused on mergers and acquisitions, information technology and transition economies that emerged from universal banking deregulation and bank privatisation. The financial crisis during 2008-2009 drew the attention of scholars to evaluate the banking performance. Idiosyncratically, this phenomenon has been acknowledged by researchers from 2010 to 2015 , focusing on the role of corporate governance in the performance of the banking industry, including compensation, risk management, determinants of stock returns, capital buffer, productivity. Idiosyncratically, a vast of studies were conducted on Chinese commercial banks and the effect on their economic growth.

In the recent period (2016-2021), diverse factors posited in the studies that dominantly present a significant interest from banking scholars. While studies earlier mainly focusing on efficiency and its contributing factors, recent periods extended research directions to multiple constituents. For example, how banks diversified their services and the role of human capital efficiency to the banking performance [37]. Bose et al. employed the effect of green banking on the performance that underpins the inclusion of the environmental sustainability approach by the banking industry [38]. Meanwhile, Bhattacharyya et al. showed the effect of CSR expenditures and financial inclusion on the performance that define the social sustainability indicator of the banks [39]. Repeatedly, the role and structure of the board, categorisation of deposits and loans, risk exposures (business cycle), macroeconomic factors were also acknowledged in recent banking performance studies [40-43]. Idiosyncratically, scholars recently focus the components of sustainability of the banking industry from economic, environmental and social aspects [44]. Furthermore, the effect of banking and its stability on economic growth has been broadly carried out in the recent period. Moreover, the development of studies was taken into account, which implies the contribution to the economic growth of particular regions. Based on the earlier and recent studies, it is precisely observed the diversification of research constituents in relation to bank performance studies. Earlier studies (up to 2015) mainly measured banking performance or efficiency based on accounting measurements, while recent studies started to include market measurements principally based on stock returns performance. On the other hand, the rise of Islamic banking and finance influenced academic researchers to compare the business models [45], banking efficiencies [46] 


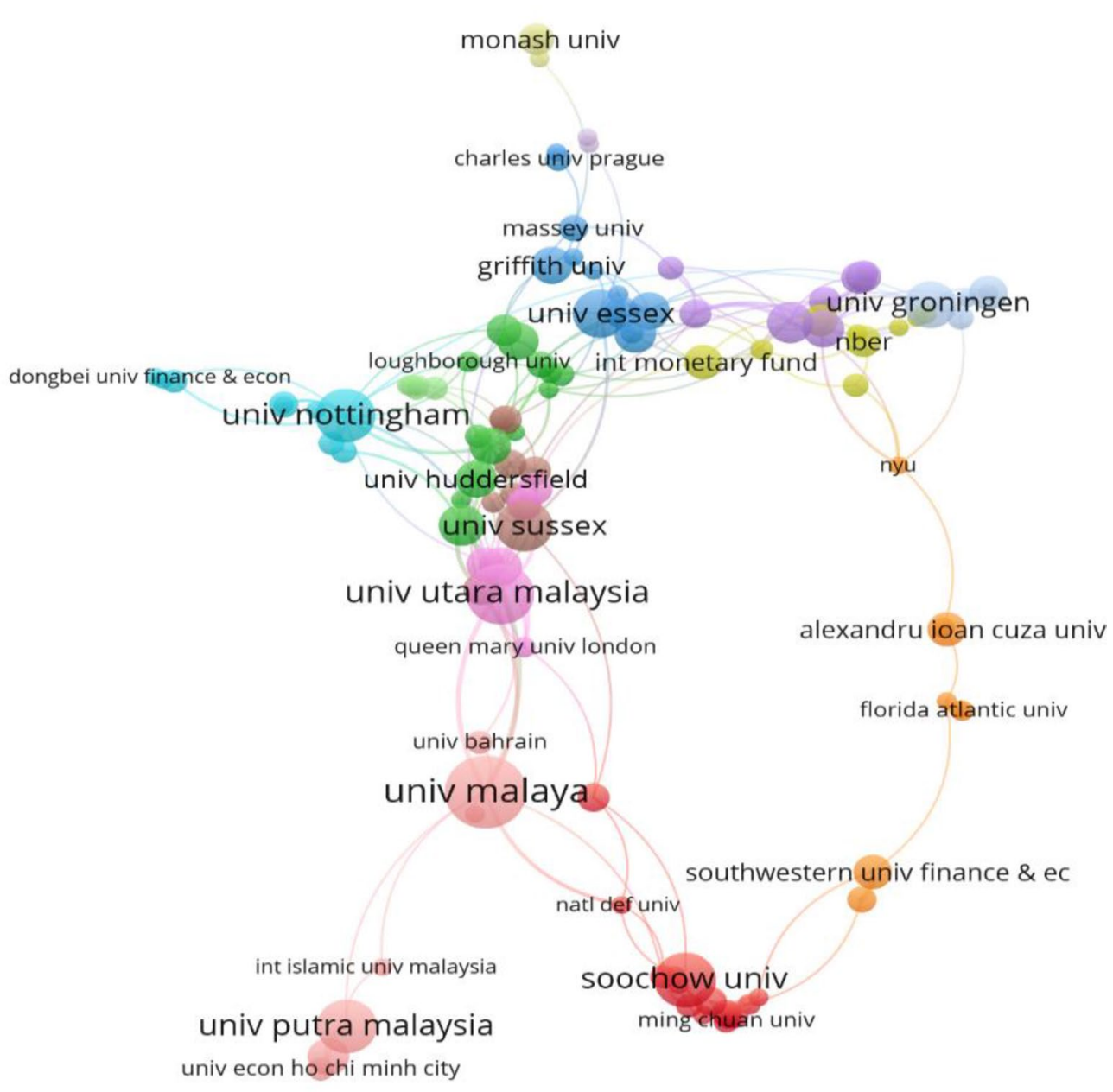

Fig. 5 Bibliographic coupling of author-affiliated institutions. Source: VOSviewer

between conventional and Islamic banks, and efficiency for Islamic banks [5].

Based on the review of impactful documents published from 1990 to 2010, two particular objectives were identified: the effect of the board of directors or ownership on the bank performance [47-49] and measurement of efficiency, including cost and profit efficiency [50-52]. These constituents extended during 2011-2020 by the inclusion of risk-taking management [53], CEO incentives [54], contributing factors including capital, banking crises on banking performance [42, 55-57]. Meanwhile, the Islamic banking system got crucial attention from academic researchers. Accordingly, several studies evaluated and compared efficiency between Islamic and conventional banks $[45,58,59]$. Nevertheless, the role of the banking industry in economic growth was included in the research constituents in the recent decade. For example, Xu, Santana and a few more scholars investigated the correlation between financial intermediation and economic growth [57, 60, 61]. In recent years, scholars extended the banking-related research constituents to diverse areas. The effect of human capital efficiency [37], green banking [38], CSR expenditures [39] and bank stability was included to measure banking performance. These extensions of research themes within banking performance studies posited a significant interest by academic researchers.

Apparently, almost all documents adopted the quantitative method in measuring banking performance research constituents. However, studies that measured banking efficiency mainly applied nonparametric analysis DEA $[5,51]$, while SFA was adopted by limited studies [37, 42, 43]. On the other hand, regression analysis was predominantly applied to investigate banking performance from 1990 to 2010 [49, 50]. In recent studies, academic researchers have vastly adopted GMM (generalised method of moments) to examine the contributing factors on banking performance $[39,42,57,60]$. These 


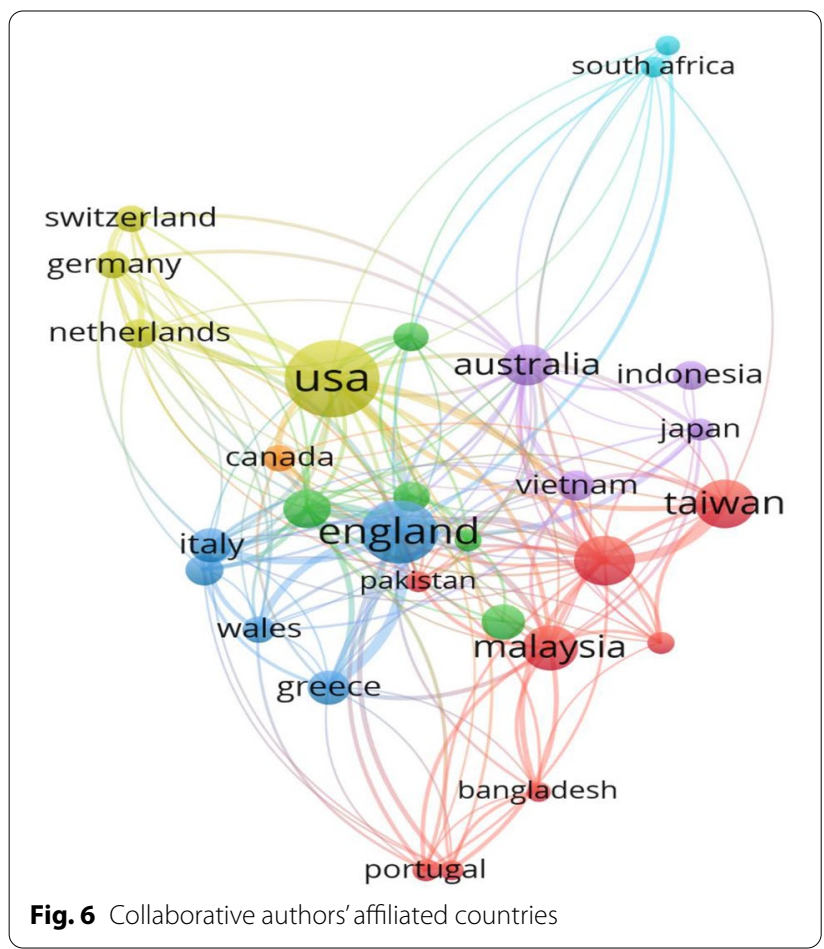

methods are dominating the banking-related studies throughout the publication periods. Over the periods, scholars have developed DEA applications in several categories, such as bootstrap, networking. Meanwhile, GMM with different approach (dynamic and system) techniques exploited panel data primarily extracted from Bankscope, Datastream, annual reports etc.

\section{Main findings}

Earlier, banking inefficiencies were substantially observed low, negatively affecting profitability and marketability $[50,51]$. This trend was continuously depicted in studies [52]. However, Berger et al. evidenced better efficiency for larger banks than smaller banks [50]. On the contrary, Seiford and Zhu posited an adverse effect of bank size on marketability [51]. More so, Rehman et al. found larger banks are less efficient than smaller banks [40]. Hence, Moudud-Ul-Huq posited diverse impacts of bank size and competition on performance [62]. So, banking size is deemed to have a substantial effect on the overall performance of banks. However, Adesina embellished that diversification of services and choices of management decisions on loans (nonperforming, debt issuances) [63, 64] and deposits [41] affect the banking performance [37]. Moreover, board structure affects banking performance [40, 65], while higher human capital efficiency enhances banking performance [37].
Generally, foreign-owned banks provide better service, greater profitability and are better efficient than local banks. This phenomenon was evidenced in several studies; for example, Bonin et al. and other scholars demonstrated that foreign-owned banks are more cost-efficient than other banks [48]. However, this trend did not exist for Islamic banks as local banks showed better efficiency than foreign peers [58] and more efficient than conventional [59]. Meanwhile, state-owned or governmentowned commercial banks were less efficient and provided poorer services $[48,49,52]$. But these banks' efficiency was higher than urban/rural banks during credit risk shock [41]. Nevertheless, banking efficiency and performance substantially depend on diversification of services, managerial adequacy, ownership, types and size.

Studies have evidenced financial development and thus the banking industry's role in economic growth [60]. In the nineteenth century, the establishment of the savings bank demonstrated city growth in Prussia [66]. Potentially, banks provide investment capital to increase per capita GDP [43]. However, Haini documented a contrasting effect of banking development on economic growth through a push out of private investment due to high levels of the banking sector [67]. However, Stewart and Chowdhury proved that a stable banking sector lessens the negative impact of a crisis on GDP growth and provides economic resilience in both developed and developing countries. Overall, findings elaborated a crucial link between banking sector development and economic growth.

\section{Future study suggestions}

This study has recommended several scopes for future studies in the hybrid review, mainly through bibliometric findings and the structured review of impactful articles [11]. In other words, the recommendations for future studies are made by observing and analysing discussions on highly cited and recent cited documents. Overall findings and analyses raised several questions that need to be addressed for future studies.

Firstly, does the banking sector improve economic growth in the least developed countries? Prior studies mainly focused on developed and developing economies, but less attention was given to least developed countries. Secondly, vast studies investigated contributing factors of banking performance, while political instability has been ignored. Future studies might include political instability on the banking performance. Apart from it, nonperforming loans can be another addition to future studies, and even few studies documented it. Thirdly, how do banks perform during the pandemic crisis, for instance, COVID-19? The current pandemic crisis can be a significant factor in banking performance related to future 


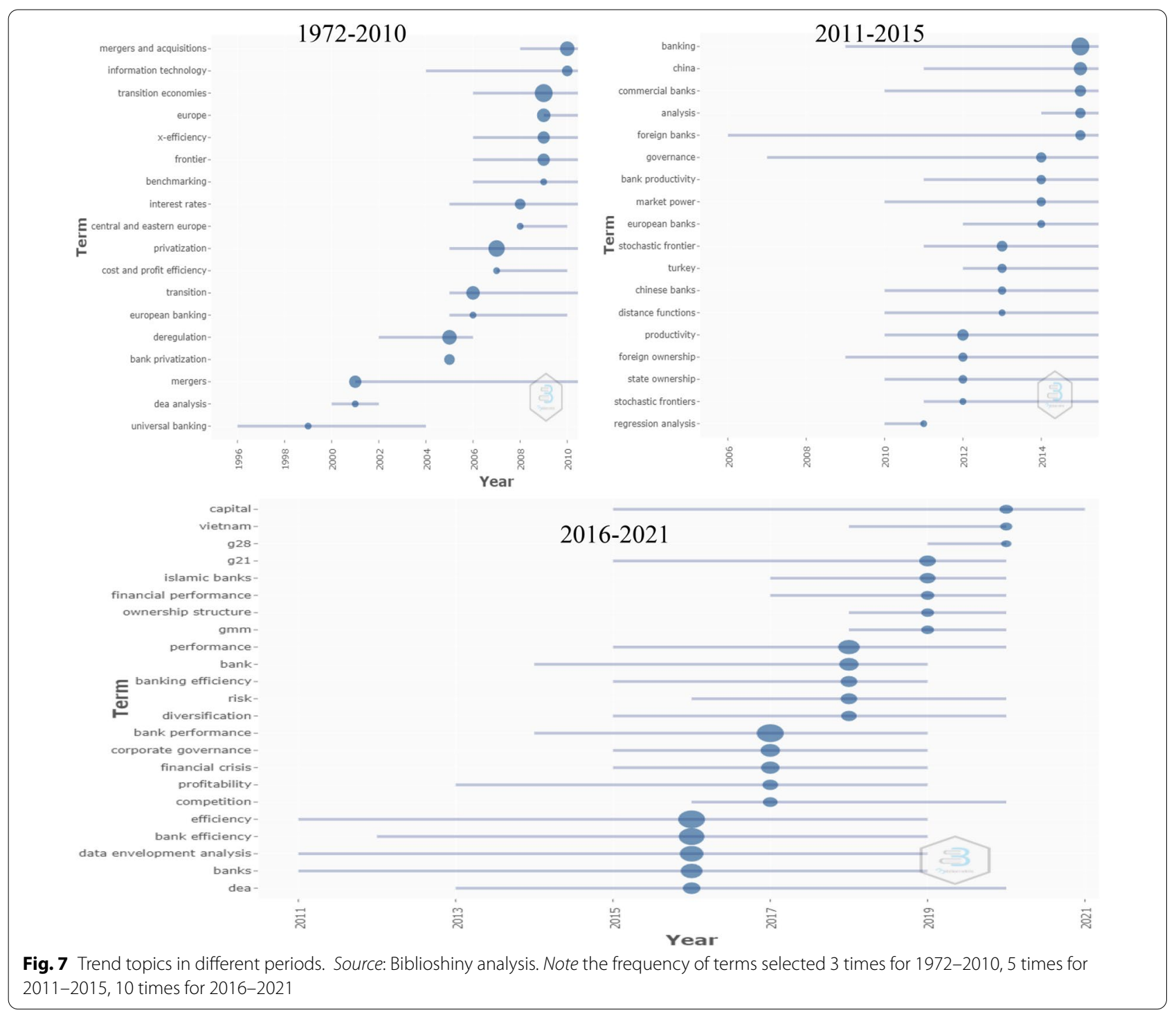

studies, including efficiency, mortgages, loan recovery, deposits and business services. The studies can include consumer behaviour (due to restricted movements, safety measurements), green banking (online transaction and services), financial technologies (inclusion of nonbanking services) and the contribution or continuance of economic activities in the country during and after the pandemic crisis.

Significantly, prior studies have ignored the current trend of FinTech inclusion in banking performance. Fourthly, will FinTech takeover the banking services and diminish banks in the near future? Future studies may investigate the effect of FinTech applications on banking. More so, future studies may explore the banking industry's barriers, challenges and threats due to FinTech growth. Fifthly, almost all studies employed quantitative analysis related to banking performance. Therefore, future studies may use qualitative methods to explore the opportunities and practices of banks and their performance. Sixthly, the majority of the studies either applied parametric or econometric techniques to investigate the bank performance. Recent developments in technologies and methods may provide easy and robust results in such related studies as using machine learning for data analysis and predicting banking efficiency and productivity determinants. Seventhly, past studies mostly followed the intermediation approach, which scarcely included production and operating approach measurement. Future studies may extend the efficiency analysis using productivity growth analysis. Further, the majority of the studies observed efficiency only. Future studies can include a productivity change index along with an efficiency 
analysis. Finally, GMM and regression were broadly applied to investigate the effect of antecedents of banking performance and link to economic growth. Future studies may adopt other advanced data analysis techniques such as partial least squares, structural equations and other econometric techniques.

\section{Conclusions}

The main purpose of this study is to explore the trends and research activities in banking performance and the economic growth research domain. To achieve this objective, a bibliometric analysis was applied and performed several analyses, namely citation, co-occurrence of keywords, the collaboration between authors and coupling between institutions and countries, and discussion by reviewing most cited and most recent influential research articles. This study presents the most common themes, sub-themes associated with highly cited documents and authors; furthermore, the content analysis identified the research directions, research objectives, methodologies, topics and findings.

Based on the reviewing literature, the efficiency theory, banking theory mainly intermediation approach and nonparametric technique, namely data envelopment analysis along with econometric method, regression was used in the published documents. The findings of this study, along with future study suggestions, could be beneficial to bankers as well as academic researchers and students studying banking performance and its role in the economy.

\section{Limitations}

The most crucial limitation in any bibliometric analysis is the database selection. It means selecting the data and the limits of its interpretation [68]. This study has three key limitations; firstly, it has chosen 'Web of Science', one of the largest online databases to gather data on banking performance research articles from 1972 to 2021 and refined based on subject categories and language (English). The database could be improved if other databases were included and also if book chapters and conference proceedings were added. Secondly, the selection of keywords; although selected keywords are deemed to be most relevant to encompass the majority of articles related to banking performance, there is always an opportunity to search further articles by using additional keywords. Lastly, this study could not conduct co-citation analysis due to the unavailability of cited documents in Web of Science data format.

\section{Appendix 1: Reviewed documents}

\begin{tabular}{|c|c|c|c|c|c|}
\hline Authors & $\begin{array}{l}\text { Type } \\
\text { of } \\
\text { paper }\end{array}$ & Objective & $\begin{array}{l}\text { Theories/ } \\
\text { approach }\end{array}$ & $\begin{array}{l}\text { Methods } \\
\text { (sample \& } \\
\text { technique) }\end{array}$ & Main findings \\
\hline $\begin{array}{l}\text { Berger } \\
\text { et al., [50] }\end{array}$ & $\begin{array}{l}\text { Quan- } \\
\text { titative }\end{array}$ & $\begin{array}{l}\text { Derived } \\
\text { profit } \\
\text { function } \\
\text { model and } \\
\text { measured } \\
\text { ineffi- } \\
\text { ciency }\end{array}$ & & $\begin{array}{l}\text { Multiple } \\
\text { regression, } \\
\text { annual } \\
\text { reports }\end{array}$ & $\begin{array}{l}\text { US banks'inefficiencies were quite large, while almost half of the potential profit vari- } \\
\text { ables were lost to inefficiency. Further, larger banks were substantially efficient than } \\
\text { smaller banks }\end{array}$ \\
\hline $\begin{array}{l}\text { Berger and } \\
\text { DeYoung } \\
{[63]}\end{array}$ & $\begin{array}{l}\text { Quan- } \\
\text { titative }\end{array}$ & $\begin{array}{l}\text { Investi- } \\
\text { gated the } \\
\text { intersec- } \\
\text { tion } \\
\text { between } \\
\text { problem } \\
\text { loan and } \\
\text { bank } \\
\text { efficiency }\end{array}$ & & $\begin{array}{l}\text { Granger- } \\
\text { causality } \\
\text { (OLS, GLS), } \\
\text { Panel data }\end{array}$ & $\begin{array}{l}\text { Problem loans and measured cost efficiency posited unidirectional links; problem loans } \\
\text { (nonperforming loans) precede reductions in cost efficiency, and cost efficiency pre- } \\
\text { cedes a reduction in problem loans }\end{array}$ \\
\hline $\begin{array}{l}\text { Seiford } \\
\text { and Zhu } \\
{[51]}\end{array}$ & $\begin{array}{l}\text { Quan- } \\
\text { titative }\end{array}$ & $\begin{array}{l}\text { Evaluated } \\
\text { the perfor- } \\
\text { mance of } \\
\text { the top } 55 \\
\text { US com- } \\
\text { mercial } \\
\text { banks }\end{array}$ & & $\begin{array}{l}\text { Output-ori- } \\
\text { ented (CCR) } \\
\text { DEA, (BCC) } \\
\text { DEA, Annual } \\
\text { reports }\end{array}$ & $\begin{array}{l}90 \% \text { of US banks were found inefficient relating to profitability and marketability. Besides, } \\
\text { bank size was suggested to have a negative effect on marketability }\end{array}$ \\
\hline
\end{tabular}




\begin{tabular}{|c|c|c|c|c|c|}
\hline Authors & $\begin{array}{l}\text { Type } \\
\text { of } \\
\text { paper }\end{array}$ & Objective & $\begin{array}{l}\text { Theories/ } \\
\text { approach }\end{array}$ & $\begin{array}{l}\text { Methods } \\
\text { (sample \& } \\
\text { technique) }\end{array}$ & Main findings \\
\hline $\begin{array}{l}\text { Bonin et al. } \\
{[49]}\end{array}$ & $\begin{array}{l}\text { Quan- } \\
\text { titative }\end{array}$ & $\begin{array}{l}\text { Exam- } \\
\text { ined the } \\
\text { effects of } \\
\text { ownership } \\
\text { on bank } \\
\text { efficiency }\end{array}$ & & $\begin{array}{l}\text { Regression } \\
\text { (stochastic } \\
\text { frontier } \\
\text { estimation), } \\
\text { panel data }\end{array}$ & $\begin{array}{l}\text { Foreign-owned banks are more cost-efficient than other banks and provide better ser- } \\
\text { vice, while government-owned banks are less efficient in providing services, and better } \\
\text { banks were privatised first in transition countries }\end{array}$ \\
\hline $\begin{array}{l}\text { Micco } \\
\text { et al. [48] }\end{array}$ & $\begin{array}{l}\text { Quan- } \\
\text { titative }\end{array}$ & $\begin{array}{l}\text { Assessed } \\
\text { the link } \\
\text { between } \\
\text { ownership } \\
\text { and bank } \\
\text { perfor- } \\
\text { mance }\end{array}$ & & $\begin{array}{l}\text { Regression, } \\
\text { panel data }\end{array}$ & $\begin{array}{l}\text { State-owned banks had lower profitability and higher costs than private banks in } \\
\text { developing countries, while foreign-owned banks showed the opposite. Further, political } \\
\text { considerations, especially during election years, differed performance between public } \\
\text { and private banks }\end{array}$ \\
\hline $\begin{array}{l}\text { Andres } \\
\text { and Valle- } \\
\text { lado [47] }\end{array}$ & $\begin{array}{l}\text { Quan- } \\
\text { titative }\end{array}$ & $\begin{array}{l}\text { Analysed } \\
\text { the effec- } \\
\text { tiveness of } \\
\text { the board } \\
\text { directors in } \\
\text { the bank }\end{array}$ & & $\begin{array}{l}\text { Regres- } \\
\text { sion (OLS, } \\
\text { system } \\
\text { estimator } \\
\text { regression), } \\
\text { Panel data }\end{array}$ & $\begin{array}{l}\text { An inverted nonlinear relationship was found between bank performance and board } \\
\text { size, between the proportion of nonexecutive directors and performance. However, } \\
\text { bank ownership, intuitional differences and weight of the banking industry differ in the } \\
\text { relationship }\end{array}$ \\
\hline $\begin{array}{l}\text { Berger } \\
\text { et al. [52] }\end{array}$ & $\begin{array}{l}\text { Quan- } \\
\text { titative }\end{array}$ & $\begin{array}{l}\text { Measured } \\
\text { cost and } \\
\text { profit } \\
\text { efficiency }\end{array}$ & & $\begin{array}{l}\text { Regression, } \\
\text { Annual } \\
\text { report }\end{array}$ & Big Chinese banks are inefficient, while foreign banks were the most efficient \\
\hline $\begin{array}{l}\text { Fahlen- } \\
\text { brach and } \\
\text { Stulz [54] }\end{array}$ & $\begin{array}{l}\text { Quan- } \\
\text { titative }\end{array}$ & $\begin{array}{l}\text { Investi- } \\
\text { gated the } \\
\text { effect of } \\
\text { CEO incen- } \\
\text { tives on } \\
\text { bank per- } \\
\text { formance } \\
\text { during the } \\
\text { crisis }\end{array}$ & & $\begin{array}{l}\text { Regression, } \\
\text { S\&P, }\end{array}$ & $\begin{array}{l}\text { Banks with higher CEOs' incentives performed worse while did not perform worse during } \\
\text { the financial crisis. CEOs had lost extremely large wealth as they did not reduce their } \\
\text { shareholdings during the crisis }\end{array}$ \\
\hline $\begin{array}{l}\text { Aebi et al. } \\
\text { [53] }\end{array}$ & $\begin{array}{l}\text { Quan- } \\
\text { titative }\end{array}$ & $\begin{array}{l}\text { Examined } \\
\text { the effect } \\
\text { of risk } \\
\text { manage- } \\
\text { ment } \\
\text { related } \\
\text { corporate } \\
\text { govern- } \\
\text { ance } \\
\text { mecha- } \\
\text { nisms on } \\
\text { bank per- } \\
\text { formance } \\
\text { during the } \\
\text { financial } \\
\text { crisis }\end{array}$ & & $\begin{array}{l}\text { Regression, } \\
\text { Panel data }\end{array}$ & $\begin{array}{l}\text { Banks'stock returns and ROE exhibited higher for those credit risk officers directly } \\
\text { reported to the board directors rather than CEO during the crisis }\end{array}$ \\
\hline $\begin{array}{l}\text { Beltratti } \\
\text { and Stulz } \\
\text { [55] }\end{array}$ & $\begin{array}{l}\text { Quan- } \\
\text { titative }\end{array}$ & $\begin{array}{l}\text { Measured } \\
\text { the con- } \\
\text { tributing } \\
\text { factors to } \\
\text { the poor } \\
\text { bank per- } \\
\text { formance } \\
\text { during the } \\
\text { credit crisis }\end{array}$ & & $\begin{array}{l}\text { Regression, } \\
\text { Panel data }\end{array}$ & $\begin{array}{l}\text { The fragility of banks financed with short term capital market funding and the better } \\
\text { performing banks had less leverage and lower returns immediate before the crisis }\end{array}$ \\
\hline
\end{tabular}




\begin{tabular}{|c|c|c|c|c|c|}
\hline Authors & $\begin{array}{l}\text { Type } \\
\text { of } \\
\text { paper }\end{array}$ & Objective & $\begin{array}{l}\text { Theories/ } \\
\text { approach }\end{array}$ & $\begin{array}{l}\text { Methods } \\
\text { (sample \& } \\
\text { technique) }\end{array}$ & Main findings \\
\hline $\begin{array}{l}\text { Berger and } \\
\text { Bouwman } \\
{[56]}\end{array}$ & $\begin{array}{l}\text { Quan- } \\
\text { titative }\end{array}$ & $\begin{array}{l}\text { Investi- } \\
\text { gated the } \\
\text { effect of } \\
\text { capital on } \\
\text { bank per- } \\
\text { formance }\end{array}$ & $\begin{array}{l}\text { The } \\
\text { screening- } \\
\text { based } \\
\text { theory, The } \\
\text { asset-sub- } \\
\text { stitution } \\
\text { moral } \\
\text { hazard } \\
\text { theories }\end{array}$ & $\begin{array}{l}\text { Logit } \\
\text { survival } \\
\text { regressions, } \\
\text { OLS }\end{array}$ & $\begin{array}{l}\text { The capital was found to enhance the survival chances and market shares of small banks } \\
\text { always even during bank crises, market crises, and normal periods. Large and medium- } \\
\text { sized banks were linked by capital predominantly during banking crises and the ones } \\
\text { with limited government intervention }\end{array}$ \\
\hline $\begin{array}{l}\text { Beck et al. } \\
{[45]}\end{array}$ & $\begin{array}{l}\text { Quan- } \\
\text { titative }\end{array}$ & $\begin{array}{l}\text { Compared } \\
\text { efficiency } \\
\text { between } \\
\text { conven- } \\
\text { tional and } \\
\text { Islamic } \\
\text { banks }\end{array}$ & & Regression & $\begin{array}{l}\text { Islamic banks had greater intermediation ratios, higher asset quality and better capitalisa- } \\
\text { tion over conventional though they were less efficient. hence, Islamic banks performed } \\
\text { better during financial crisis regards of asset quality and capitalisation }\end{array}$ \\
\hline $\mathrm{Xu}[60]$ & $\begin{array}{l}\text { Quan- } \\
\text { titative }\end{array}$ & $\begin{array}{l}\text { Investi- } \\
\text { gated the } \\
\text { relation- } \\
\text { ship } \\
\text { between } \\
\text { financial } \\
\text { intermedi- } \\
\text { ation and } \\
\text { economic } \\
\text { growth }\end{array}$ & & $\begin{array}{l}\text { System } \\
\text { GMM, } \\
\text { dynamic } \\
\text { panel data }\end{array}$ & $\begin{array}{l}\text { A diverse measure of financial development was generally linked to economic growth. } \\
\text { The size and depth of the financial sector significantly influence economic growth }\end{array}$ \\
\hline $\begin{array}{l}\text { Kamarudin } \\
\text { et al. [58] }\end{array}$ & $\begin{array}{l}\text { Quan- } \\
\text { titative }\end{array}$ & $\begin{array}{l}\text { Examined } \\
\text { and com- } \\
\text { pared the } \\
\text { efficiency } \\
\text { of domes- } \\
\text { tic and } \\
\text { foreign } \\
\text { Islamic } \\
\text { banks in } \\
\text { SEA coun- } \\
\text { tries }\end{array}$ & & $\begin{array}{l}\text { DEA, Annual } \\
\text { Reports }\end{array}$ & Domestic Islamic had greater efficiency than foreign banks peer \\
\hline $\begin{array}{l}\text { Moudud- } \\
\text { Ul-Huq } \\
{[42]}\end{array}$ & $\begin{array}{l}\text { Quan- } \\
\text { titative }\end{array}$ & $\begin{array}{l}\text { Investi- } \\
\text { gated the } \\
\text { linkage } \\
\text { between } \\
\text { capital } \\
\text { buffer, } \\
\text { risk and } \\
\text { efficiency } \\
\text { adjust- } \\
\text { ments }\end{array}$ & & $\begin{array}{l}\text { SFA, GMM, } \\
\text { panel data }\end{array}$ & $\begin{array}{l}\text { The economic cycle had a substantial effect on capital holding, risk and efficiency adjust- } \\
\text { ments. Besides, high capitalised banks posited less efficient than low capitalised banks } \\
\text { due to enact of regulatory pressure }\end{array}$ \\
\hline $\begin{array}{l}\text { Buallay } \\
\text { et al. [44] }\end{array}$ & $\begin{array}{l}\text { Quan- } \\
\text { titative }\end{array}$ & $\begin{array}{l}\text { Examined } \\
\text { the rela- } \\
\text { tionship } \\
\text { between } \\
\text { sustain- } \\
\text { ability } \\
\text { reporting } \\
\text { and bank } \\
\text { perfor- } \\
\text { mance } \\
\text { after finan- } \\
\text { cial crisis }\end{array}$ & $\begin{array}{l}\text { Value } \\
\text { creation } \\
\text { theory }\end{array}$ & $\begin{array}{l}\text { Regression, } \\
\text { GMM, panel } \\
\text { data }\end{array}$ & $\begin{array}{l}\text { Environmental, social, and governance scores lessen banking performance in both } \\
\text { developed and developing countries }\end{array}$ \\
\hline
\end{tabular}




\begin{tabular}{|c|c|c|c|c|c|}
\hline Authors & $\begin{array}{l}\text { Type } \\
\text { of } \\
\text { paper }\end{array}$ & Objective & $\begin{array}{l}\text { Theories/ } \\
\text { approach }\end{array}$ & $\begin{array}{l}\text { Methods } \\
\text { (sample \& } \\
\text { technique) }\end{array}$ & Main findings \\
\hline $\begin{array}{l}\text { Chowd- } \\
\text { hury et al. } \\
{[59]}\end{array}$ & $\begin{array}{l}\text { Quan- } \\
\text { titative }\end{array}$ & $\begin{array}{l}\text { Meas- } \\
\text { ured and } \\
\text { compared } \\
\text { efficiency } \\
\text { between } \\
\text { Islamic and } \\
\text { conven- } \\
\text { tional } \\
\text { banks }\end{array}$ & & $\begin{array}{l}\text { DEA, } \\
\text { Malmquist, } \\
\text { Annual } \\
\text { reports }\end{array}$ & $\begin{array}{l}\text { Islamic banks exhibited better comparably in efficiency than conventional. All commer- } \\
\text { cial banks need to improve managerial efficiency }\end{array}$ \\
\hline $\begin{array}{l}\text { Moudud- } \\
\text { Ul-Huq } \\
{[62]}\end{array}$ & $\begin{array}{l}\text { Quan- } \\
\text { titative }\end{array}$ & $\begin{array}{l}\text { Investi- } \\
\text { gated the } \\
\text { relation- } \\
\text { ship } \\
\text { between } \\
\text { risk-taking } \\
\text { behaviour } \\
\text { and banks' } \\
\text { competi- } \\
\text { tion per- } \\
\text { formance }\end{array}$ & $\begin{array}{l}\text { competi- } \\
\text { tion-stabil- } \\
\text { ity theory, } \\
\text { quiet life } \\
\text { hypothesis. } \\
\text { Structure- } \\
\text { conduct- } \\
\text { perfor- } \\
\text { mance }\end{array}$ & $\begin{array}{l}\text { GMM, panel } \\
\text { data }\end{array}$ & $\begin{array}{l}\text { Bank size heterogeneously affects bank performance and risk-taking behaviour in } \\
\text { emerging countries, and competition substantially affects bank performance }\end{array}$ \\
\hline $\begin{array}{l}\text { Santana } \\
{[57]}\end{array}$ & $\begin{array}{l}\text { Quan- } \\
\text { titative }\end{array}$ & $\begin{array}{l}\text { Investi- } \\
\text { gated the } \\
\text { effects of } \\
\text { banking } \\
\text { crises and } \\
\text { financial } \\
\text { liberalisa- } \\
\text { tion on the } \\
\text { relation- } \\
\text { ship } \\
\text { between } \\
\text { financial } \\
\text { develop- } \\
\text { ment and } \\
\text { economic } \\
\text { growth }\end{array}$ & & $\begin{array}{l}\text { GMM, } \\
\text { Dynamic } \\
\text { panel data }\end{array}$ & $\begin{array}{l}\text { Financial liberalisation did not show a positive relationship between financial develop- } \\
\text { ment and economic growth due to the emergence and recurrence of banking crises }\end{array}$ \\
\hline $\begin{array}{l}\text { Zeqiraj } \\
\text { et al. [61] }\end{array}$ & $\begin{array}{l}\text { Quan- } \\
\text { titative }\end{array}$ & $\begin{array}{l}\text { Investi- } \\
\text { gated the } \\
\text { dynamic } \\
\text { impact of } \\
\text { banking } \\
\text { sector } \\
\text { perfor- } \\
\text { mance on } \\
\text { economic } \\
\text { growth }\end{array}$ & & $\begin{array}{l}\text { GMM, } \\
\text { Dynamic } \\
\text { panel data }\end{array}$ & $\begin{array}{l}\text { The banking sector showed a significant positive effect on economic growth. It implied } \\
\text { that banking efficiency is one of the key determinants of overall economic growth }\end{array}$ \\
\hline $\begin{array}{l}\text { Adesina } \\
{[37]}\end{array}$ & $\begin{array}{l}\text { Quan- } \\
\text { titative }\end{array}$ & $\begin{array}{l}\text { Examined } \\
\text { the effect } \\
\text { of human } \\
\text { capital } \\
\text { efficiency } \\
\text { on the link } \\
\text { between } \\
\text { diversifica- } \\
\text { tion and } \\
\text { bank per- } \\
\text { formance }\end{array}$ & $\begin{array}{l}\text { Interme- } \\
\text { diation }\end{array}$ & $\begin{array}{l}\text { SFA, Tobit } \\
\text { regression }\end{array}$ & $\begin{array}{l}\text { Higher diversification reduces bank performance in three ways; cost efficiency, profitabil- } \\
\text { ity and financial stability. Hence, higher levels of human capital efficiency were positively } \\
\text { relating to bank performance }\end{array}$ \\
\hline
\end{tabular}




\begin{tabular}{|c|c|c|c|c|c|}
\hline Authors & $\begin{array}{l}\text { Type } \\
\text { of } \\
\text { paper }\end{array}$ & Objective & $\begin{array}{l}\text { Theories/ } \\
\text { approach }\end{array}$ & $\begin{array}{l}\text { Methods } \\
\text { (sample \& } \\
\text { technique) }\end{array}$ & Main findings \\
\hline $\begin{array}{l}\text { Bose et al. } \\
{[38]}\end{array}$ & $\begin{array}{l}\text { Quan- } \\
\text { titative }\end{array}$ & $\begin{array}{l}\text { Inves- } \\
\text { tigated } \\
\text { the effect } \\
\text { of green } \\
\text { banking to } \\
\text { improve } \\
\text { banks' } \\
\text { financial } \\
\text { perfor- } \\
\text { mance }\end{array}$ & & $\begin{array}{l}\text { Regression } \\
\text { (OLS), panel } \\
\text { data, annual } \\
\text { reports }\end{array}$ & $\begin{array}{l}\text { A positive relationship was found between green banking and banks' financial per- } \\
\text { formance, while cost-efficiency moderated this relationship. However, banks' political } \\
\text { connection negatively driven this relationship }\end{array}$ \\
\hline $\begin{array}{l}\text { Bhattacha- } \\
\text { ryya et al. } \\
\text { [39] }\end{array}$ & $\begin{array}{l}\text { Quan- } \\
\text { titative }\end{array}$ & $\begin{array}{l}\text { Investi- } \\
\text { gated the } \\
\text { relation- } \\
\text { ship of CSR } \\
\text { expendi- } \\
\text { tures and } \\
\text { financial } \\
\text { inclusion } \\
\text { on bank- } \\
\text { ing perfor- } \\
\text { mance }\end{array}$ & $\begin{array}{l}\text { Freeman's } \\
\text { stake- } \\
\text { holder } \\
\text { theory, }\end{array}$ & $\begin{array}{l}\text { GMM, panel } \\
\text { data }\end{array}$ & $\begin{array}{l}\text { In terms of accounting measurement, CSR expenditure and degree of financial inclusion } \\
\text { were not linked to banks' financial performance, while a negative link was found in terms } \\
\text { of the stock market return }\end{array}$ \\
\hline $\begin{array}{l}\text { Chen and } \\
\text { Lu [43] }\end{array}$ & $\begin{array}{l}\text { Quan- } \\
\text { titative }\end{array}$ & $\begin{array}{l}\text { Examine } \\
\text { the impact } \\
\text { of the } \\
\text { regional } \\
\text { disparities } \\
\text { in the cost } \\
\text { and profit } \\
\text { efficiency }\end{array}$ & $\begin{array}{l}\text { Interme- } \\
\text { diation }\end{array}$ & $\begin{array}{l}\text { SFA, Annual } \\
\text { reports }\end{array}$ & $\begin{array}{l}\text { Banking efficiency had a positive correlation to per capita GDP while negatively related } \\
\text { to the urban population ratio }\end{array}$ \\
\hline $\begin{array}{l}\text { Chowd- } \\
\text { hury and } \\
\text { Haron [5] }\end{array}$ & $\begin{array}{l}\text { Quan- } \\
\text { titative }\end{array}$ & $\begin{array}{l}\text { Measured } \\
\text { efficiency } \\
\text { of SEA } \\
\text { Islamic } \\
\text { banks }\end{array}$ & $\begin{array}{l}\text { Interme- } \\
\text { diation }\end{array}$ & $\begin{array}{l}\text { DEA, } \\
\text { Malmquist, } \\
\text { Annual } \\
\text { reports }\end{array}$ & Islamic banks have improved inefficiency in the region \\
\hline $\begin{array}{l}\text { Gaies and } \\
\text { Nabi [69] }\end{array}$ & $\begin{array}{l}\text { Quan- } \\
\text { titative }\end{array}$ & $\begin{array}{l}\text { Exam- } \\
\text { ined the } \\
\text { interaction } \\
\text { between } \\
\text { FDl and } \\
\text { external } \\
\text { debt }\end{array}$ & $\begin{array}{l}\text { The over- } \\
\text { lapping } \\
\text { generation } \\
\text { growth } \\
\text { model }\end{array}$ & $\begin{array}{l}\text { GMM, panel } \\
\text { data }\end{array}$ & $\begin{array}{l}\text { Banks posited an effect on economic growth. External debt financial enhanced vulner- } \\
\text { ability to a bank operation that generates a recessionary effect on economic growth }\end{array}$ \\
\hline Haini [67] & $\begin{array}{l}\text { Quan- } \\
\text { titative }\end{array}$ & $\begin{array}{l}\text { Investi- } \\
\text { gated the } \\
\text { nonlinear } \\
\text { impact of } \\
\text { banking } \\
\text { sector } \\
\text { develop- } \\
\text { ment on } \\
\text { economic } \\
\text { growth }\end{array}$ & & $\begin{array}{l}\text { GMM, } \\
\text { dynamic } \\
\text { panel data }\end{array}$ & $\begin{array}{l}\text { A nonlinear relationship was found between banking sector development and eco- } \\
\text { nomic growth. High levels of banking sector development push out the positive effect } \\
\text { of private investment }\end{array}$ \\
\hline $\begin{array}{l}\text { Isnurhadi } \\
\text { et al. [70] }\end{array}$ & $\begin{array}{l}\text { Quan- } \\
\text { titative }\end{array}$ & $\begin{array}{l}\text { Evaluated } \\
\text { the rela- } \\
\text { tionship } \\
\text { between } \\
\text { bank } \\
\text { capital, } \\
\text { efficiency, } \\
\text { and risk } \\
\text { in Islamic } \\
\text { banks }\end{array}$ & & $\begin{array}{l}\text { Pooled OLS } \\
\text { and Ran- } \\
\text { dom Effect } \\
\text { (RE), panel } \\
\text { data }\end{array}$ & $\begin{array}{l}\text { Bank capital positively affects bank stability and negatively on credit risk and efficiency. } \\
\text { hence, efficiency encouraged banks to lessen risk even when the capital was lower }\end{array}$ \\
\hline
\end{tabular}




\begin{tabular}{|c|c|c|c|c|c|}
\hline Authors & $\begin{array}{l}\text { Type } \\
\text { of } \\
\text { paper }\end{array}$ & Objective & $\begin{array}{l}\text { Theories/ } \\
\text { approach }\end{array}$ & $\begin{array}{l}\text { Methods } \\
\text { (sample \& } \\
\text { technique) }\end{array}$ & Main findings \\
\hline $\begin{array}{l}\text { Kchikeche } \\
\text { and Khal- } \\
\text { louk [71] }\end{array}$ & $\begin{array}{l}\text { Quan- } \\
\text { titative }\end{array}$ & $\begin{array}{l}\text { Exam- } \\
\text { ined the } \\
\text { causal link } \\
\text { between } \\
\text { banking } \\
\text { financial } \\
\text { develop- } \\
\text { ment and } \\
\text { economic } \\
\text { growth }\end{array}$ & & $\begin{array}{l}\text { Vector } \\
\text { autore- } \\
\text { gression } \\
\text { framework }\end{array}$ & $\begin{array}{l}\text { Bank-based financial development affected economic growth in both the short and } \\
\text { long run }\end{array}$ \\
\hline $\begin{array}{l}\text { Lehmann- } \\
\text { Hase- } \\
\text { meyer and } \\
\text { Wahl [66] }\end{array}$ & $\begin{array}{l}\text { Quan- } \\
\text { titative }\end{array}$ & $\begin{array}{l}\text { Revisited } \\
\text { the effect } \\
\text { of saving } \\
\text { banks on } \\
\text { economic } \\
\text { develop- } \\
\text { ment in } \\
\text { Prussia }\end{array}$ & & $\begin{array}{l}\text { Regres- } \\
\text { sion (fixed } \\
\text { effects) }\end{array}$ & $\begin{array}{l}\text { A significant positive relationship was demonstrated between the establishment of sav- } \\
\text { ing banks and city growth in the nineteenth century }\end{array}$ \\
\hline $\begin{array}{l}\text { Li et al. } \\
{[72]}\end{array}$ & $\begin{array}{l}\text { Quan- } \\
\text { titative }\end{array}$ & $\begin{array}{l}\text { Investi- } \\
\text { gated the } \\
\text { impact of } \\
\text { credit risk } \\
\text { shocks } \\
\text { on the } \\
\text { evolution } \\
\text { of banking } \\
\text { efficiency }\end{array}$ & $\begin{array}{l}\text { Efficiency } \\
\text { theory }\end{array}$ & $\begin{array}{l}\text { DEA (boot- } \\
\text { strap-DEA), } \\
\text { annual } \\
\text { report }\end{array}$ & $\begin{array}{l}\text { The efficiency of both state-owned and joint-stock commercial banks was higher than } \\
\text { urban/rural commercial banks during a credit risk shock }\end{array}$ \\
\hline $\begin{array}{l}\text { Rehman } \\
\text { et al. [40] }\end{array}$ & $\begin{array}{l}\text { Quan- } \\
\text { titative }\end{array}$ & $\begin{array}{l}\text { Exam- } \\
\text { ined the } \\
\text { effect of } \\
\text { reformed } \\
\text { bank } \\
\text { sectors on } \\
\text { the rela- } \\
\text { tionship } \\
\text { between } \\
\text { bank per- } \\
\text { formance } \\
\text { and board } \\
\text { structure }\end{array}$ & $\begin{array}{l}\text { Soft- } \\
\text { budget } \\
\text { constraint, } \\
\text { interme- } \\
\text { diation }\end{array}$ & $\begin{array}{l}\text { SFA, DEA, } \\
\text { Regression, } \\
\text { panel data }\end{array}$ & $\begin{array}{l}\text { A negative link was found between board independence and banking efficiency; how- } \\
\text { ever, it became positive when banks were listed in the stock market. Larger banks are } \\
\text { less efficient than smaller banks }\end{array}$ \\
\hline $\begin{array}{l}\text { Ryu and } \\
\text { Yu [64] }\end{array}$ & $\begin{array}{l}\text { Quan- } \\
\text { titative }\end{array}$ & $\begin{array}{l}\text { Examined } \\
\text { the nonlin- } \\
\text { ear effect } \\
\text { on bank } \\
\text { perfor- } \\
\text { mance due } \\
\text { to changes } \\
\text { in subor- } \\
\text { dinated } \\
\text { debt }\end{array}$ & & $\begin{array}{l}\text { Regression } \\
(\text { FE, RE), } \\
\text { panel data }\end{array}$ & $\begin{array}{l}\text { Debt issuances adversely and significantly affected bank performance, and redemptions } \\
\text { did not boost up this effect }\end{array}$ \\
\hline $\begin{array}{l}\text { Stewart } \\
\text { and } \\
\text { Chowd- } \\
\text { hury [73] }\end{array}$ & $\begin{array}{l}\text { Quan- } \\
\text { titative }\end{array}$ & $\begin{array}{l}\text { Investigate } \\
\text { the effect } \\
\text { of bank } \\
\text { stability, } \\
\text { liquidity } \\
\text { and capital } \\
\text { on the } \\
\text { relation- } \\
\text { ship } \\
\text { between } \\
\text { output } \\
\text { growth } \\
\text { and bank } \\
\text { crises }\end{array}$ & & $\begin{array}{l}\text { GMM, Panel } \\
\text { data }\end{array}$ & $\begin{array}{l}\text { A stable banking sector reduces the negative effect of a crisis on GDP growth further } \\
\text { provides economic resilience in developed and developing countries }\end{array}$ \\
\hline
\end{tabular}




\begin{tabular}{|c|c|c|c|c|c|}
\hline Authors & $\begin{array}{l}\text { Type } \\
\text { of } \\
\text { paper }\end{array}$ & Objective & $\begin{array}{l}\text { Theories/ } \\
\text { approach }\end{array}$ & $\begin{array}{l}\text { Methods } \\
\text { (sample \& } \\
\text { technique) }\end{array}$ & Main findings \\
\hline $\begin{array}{l}\text { Tam et al. } \\
{[65]}\end{array}$ & $\begin{array}{l}\text { Quan- } \\
\text { titative }\end{array}$ & $\begin{array}{l}\text { Investi- } \\
\text { gated the } \\
\text { effect of } \\
\text { inde- } \\
\text { pendent } \\
\text { directions } \\
\text { on bank } \\
\text { perfor- } \\
\text { mance }\end{array}$ & & $\begin{array}{l}\text { Regression, } \\
\text { panel data }\end{array}$ & $\begin{array}{l}\text { Independent directors with a higher board hierarchy positively affect the bank perfor- } \\
\text { mance and cost-efficiency, while the negative effect was estimated on the variability of } \\
\text { performances }\end{array}$ \\
\hline $\begin{array}{l}\text { Yu et al. } \\
{[41]}\end{array}$ & $\begin{array}{l}\text { Quan- } \\
\text { titative }\end{array}$ & $\begin{array}{l}\text { Assessed } \\
\text { the } \\
\text { dynamic } \\
\text { perfor- } \\
\text { mance of } \\
\text { banks }\end{array}$ & & $\begin{array}{l}\text { DEA, panel } \\
\text { data and } \\
\text { annual } \\
\text { reports }\end{array}$ & $\begin{array}{l}\text { Inefficiency in the deposit process caused the overall inefficiency of the banks; thus, } \\
\text { improvement in deposit efficiency was more important than lending efficiency }\end{array}$ \\
\hline
\end{tabular}

\section{Abbreviations}

DEA: Data envelopment analysis; GMM: Generalized method of moments; WoS: Web of Science; Cl: Collaboration index; CEO: Chief executive officer; CSR: Corporate social responsibility.

\section{Acknowledgements}

$\mathrm{N} / \mathrm{A}$

\section{Authors' contributions}

MAMC conducted the data analysis. SMSA prepared the manuscript by contributing literature and discussion for this study. DBAR managed the data and edited the manuscript. All authors read and approved the final manuscript.

\section{Funding}

N/A

\section{Availability of data and materials}

The data collected from the Web of Science online database were saved on Microsoft excel and remained with authors. The data are available upon request.

\section{Declarations}

\section{Competing interest}

We have no conflicts of interest to disclose.

Received: 24 August 2021 Accepted: 30 November 2021 Published: 14 December 2021

\section{References}

1. Berger AN, Demsetz RS, Strahan PE (1999) The consolidation of the financial services industry: causes, consequences, and implications for the future. J Bank Finance 23(2):135-194. https://doi.org/10.1016/S03784266(98)00125-3

2. Beckett A, Hewer P, Howcroft B (2000) An exposition of consumer behaviour in the financial services industry. Int J Bank Mark 18(1):15-26. https:// doi.org/10.1108/02652320010315325

3. Berger AN (2000) The integration of the Financial Services Industry. North Am Actuar J 4(3):25-45. https://doi.org/10.1080/10920277.2000.10595 922

4. Ndubuisi MN, Chikeziem FO (2014) Banks' Credit as an instrument of economic growth in Nigeria. Int J Bus Law Res 2(2):25-33

5. Chowdhury MAM, Haron R (2021) The efficiency of Islamic Banks in the Southeast Asia (SEA) region. Future Bus J 7(16):1-16. https://doi.org/10. 1186/s43093-021-00062-z
6. Jiang Y, Li M, Xia P (2021) Bank supply chain efficiency analysis based on regional heterogeneity: a data-driven empirical study. Ind Manag Data Syst 121(4):940-963. https://doi.org/10.1108/IMDS-10-2019-0541

7. Moez D (2020) Does unsystematic risk management affect the relationship between banks' performance and the objectives of Saudi Arabia Economic Vision 2030? Acad Account Financ Stud J 24(4):1-15

8. Sweileh WM, Al-Jabi SW, AbuTaha AS, Zyoud SH, Anayah FMA, Sawalha AF (2017) Bibliometric analysis of worldwide scientific literature in mobile - health: 2006-2016. BMC Med Inform Decis Mak 17(1):1-12. https://doi.org/10.1186/s12911-017-0476-7

9. Donthu N, Kumar S, Mukherjee D, Pandey N, Lim WM (2021) How to conduct a bibliometric analysis: an overview and guidelines. J Bus Res 133(May):285-296. https://doi.org/10.1016/j.jbusres.2021.04.070

10. Pritchard A (1969) Statistical bibliography or bibliometrics? J Doc 25(4):348-349

11. Paul J, Criado AR (2020) The art of writing literature review: what do we know and what do we need to know? Int Bus Rev 29(4):101717. https://doi.org/10.1016/j.ibusrev.2020.101717

12. Sweileh WM (2020) Bibliometric analysis of peer-reviewed literature on climate change and human health with an emphasis on infectious diseases. Glob Health 16(1):1-17. https://doi.org/10.1186/ s12992-020-00576-1

13. Verma S, Gustafsson A (2020) Investigating the emerging COVID-19 research trends in the field of business and management: a bibliometric analysis approach. J Bus Res 118(January):253-261. https://doi.org/ 10.1016/j.jbusres.2020.06.057

14. Cvetkoska V, Savic G (2021) DEA in banking: analysis and visualization of bibliometric data. Data Envel Anal J 5(2):455-485. https://doi.org/10. $1561 / 103.00000044$

15. Ikra SS, Rahman MA, Wanke P, Azad MAK (2021) Islamic banking efficiency literature (2000-2020): a bibliometric analysis and research front mapping. Int J Islam Middle Eastern Finance Manag. https://doi.org/10. 1108/imefm-05-2020-0226 (ahead-of-p(ahead-of-print))

16. Bretas VPG, Alon I (2021) Franchising research on emerging markets: bibliometric and content analyses. J Bus Res 133(May):51-65. https:// doi.org/10.1016/j.jbusres.2021.04.067

17. Nobanee $H$ (2021) A bibliometric review of big data in finance. Big Data 9(2):73-78. https://doi.org/10.1089/big.2021.29044.edi

18. Durieux V, Gevenois PA (2010) Bibliometric indicators: quality measurements of scientific publication. Radiology 255(2):342-351. https://doi. org/10.1148/radiol.09090626

19. Gaur A, Kumar M (2018) A systematic approach to conducting review studies: an assessment of content analysis in 25 years of IB research. J World Bus 53(2):280-289. https://doi.org/10.1016/j.jwb.2017.11.003

20. Aria M, Cuccurullo C (2017) bibliometrix: an R-tool for comprehensive science mapping analysis. J Informet 11(4):959-975. https://doi.org/10. 1016/j.joi.2017.08.007 
21. Bahoo S, Alon I, Paltrinieri A (2020) Sovereign wealth funds: past, present and future. Int Rev Financ Anal 67(October):101418. https://doi. org/10.1016/j.irfa.2019.101418

22. Alon I, Anderson J, Munim ZH, Ho A (2018) A review of the internationalization of Chinese enterprises. Asia Pac J Manag 35(3):573-605. https://doi.org/10.1007/s10490-018-9597-5

23. Apriliyanti ID, Alon I (2017) Bibliometric analysis of absorptive capacity. Int Bus Rev 26(5):896-907. https://doi.org/10.1016/j.ibusrev.2017.02 007

24. Cobo MJ, Herrera F (2011) An approach for detecting, quantifying, and visualizing the evolution of a research field: a practical application to the Fuzzy Sets Theory field. J Informet 5(1):146-166. https://doi.org/10. 1016/j.joi.2010.10.002

25. Fraser DR, Rose PS (1972) Bank entry and bank performance. J Financ 27(1):65-78. https://doi.org/10.2307/2978504

26. Baker HK, Kumar S, Pandey N (2021) Forty years of the journal of futures markets: a bibliometric overview. J Futur Mark 41(7):1027-1054. https://doi.org/10.1002/fut.22211

27. Baker HK, Kumar S, Pandey N (2020) A bibliometric analysis of managerial finance: a retrospective. Manag Finance 46(11):1495-1517. https://doi. org/10.1108/MF-06-2019-0277

28. Appio FP, Cesaroni F, Di Minin A (2014) Visualizing the structure and bridges of the intellectual property management and strategy literature: a document co-citation analysis. Scientometrics 101(1):623-661. https:// doi.org/10.1007/s11192-014-1329-0

29. Fahimnia B, Sarkis J, Davarzani H (2015) Green supply chain management: a review and bibliometric analysis. Int J Prod Econ 162:101-114. https:// doi.org/10.1016/j.ijpe.2015.01.003

30. Callon M, Courtial J-P, Turner WA, Bauin S (1983) From translations to problematic networks: an introduction to co-word analysis. Soc Sci Inf 22(2):191-235. https://doi.org/10.1177/053901883022002003

31. Donthu N, Kumar S, Pattnaik D (2020) Forty-five years of Journal of Business Research: a bibliometric analysis. J Bus Res 109(October 2019):1-14. https://doi.org/10.1016/j.jbusres.2019.10.039

32. Emich KJ, Kumar S, Lu L, Norder K, Pandey N (2020) Mapping 50 years of small group research through small group research. Small Group Res 51(6):659-699. https://doi.org/10.1177/1046496420934541

33. Acedo FJ, Barroso C, Casanueva C, Galán JL (2006) Co-authorship in management and organizational studies: an empirical and network analysis. J Manag Stud 43(5):957-983. https://doi.org/10.1111/j.1467-6486.2006. 00625.x

34. Cisneros L, Ibanescu M, Keen C, Lobato-Calleros O, Niebla-Zatarain J (2018) Bibliometric study of family business succession between 1939 and 2017: mapping and analyzing authors' networks. Scientometrics. https://doi.org/10.1007/s11192-018-2889-1

35. Tahamtan I, SafipourAfshar A, Ahamdzadeh K (2016) Factors affecting number of citations: a comprehensive review of the literature. Scientometrics 107(3):1 195-1225. https://doi.org/10.1007/s11192-016-1889-2

36. Crane D (1972) Invisible colleges: diffusion of knowledge in scientific communities. University of Chicago Press

37. Adesina KS (2021) How diversification affects bank performance: the role of human capital. Econ Model 94:303-319. https://doi.org/10.1016/j. econmod.2020.10.016

38. Bose S, Khan HZ, Monem RM (2021) Does green banking performance pay off? Evidence from a unique regulatory setting in Bangladesh. Corp Gov Int Rev 29(2):162-187. https://doi.org/10.1111/corg.12349

39. Bhattacharyya A, Wright S, Rahman ML (2021) Is better banking performance associated with financial inclusion and mandated CSR expenditure in a developing country? Account Finance 61 (1):125-161. https:// doi.org/10.1111/acfi.12560

40. Rehman RU, Zhang J, Naseem MA, Ahmed MI, Ali R (2021) Board independence and Chinese banking efficiency: a moderating role of ownership restructuring. Eurasian Bus Rev 11(3):517-536. https://doi.org/ 10.1007/s40821-020-00155-9

41. Yu MM, Lin Cl, Chen KC, Chen LH (2021) Measuring Taiwanese bank performance: a two-system dynamic network data envelopment analysis approach. Omega (United Kingdom) 98:102145. https://doi.org/10.1016/j. omega.2019.102145

42. Moudud-Ul-Huq S (2019) The impact of business cycle on banks' capital buffer, risk and efficiency: a dynamic GMM approach from a developing economy. Glob Bus Rev. https://doi.org/10.1177/0972150918817382
43. Chen X, Lu CC (2021) The impact of the macroeconomic factors in the bank efficiency: evidence from the Chinese city banks. North Am J Econ Finance 55:101294. https://doi.org/10.1016/j.najef.2020.101294

44. Buallay A, Fadel SM, Alajmi J, Saudagaran S (2020) Sustainability reporting and bank performance after financial crisis: evidence from developed and developing countries. Compet Rev 31(4):747-770. https://doi.org/10. 1108/CR-04-2019-0040

45. BeckT, Demirgüç-kunt $A$, Merrouche $O$ (2013) Islamic vs. conventional banking: business model, efficiency and stability. J Bank Finance 37(2):433-447. https://doi.org/10.1016/j.jbankfin.2012.09.016

46. Kamarudin F, Nordin BAA, Muhammad J, Hamid MAA (2014) Cost, revenue and profit efficiency of Islamic and conventional banking sector: empirical evidence from gulf cooperative council countries. Glob Bus Rev 15(1):1-24. https://doi.org/10.1177/0972150913515579

47. de Andres P, Vallelado E (2008) Corporate governance in banking: The role of the board of directors. J Bank Finance 32(12):2570-2580. https:// doi.org/10.1016/j.jbankfin.2008.05.008

48. Micco A, Panizza U, Yañez M (2007) Bank ownership and performance. Does politics matter? J Bank Finance 31(1):219-241. https://doi.org/10. 1016/j.jbankfin.2006.02.007

49. Bonin JP, Hasan I, Wachtel P (2005) Bank performance, efficiency and ownership in transition countries. J Bank Finance 29(1 SPEC. ISS.):31-53. https://doi.org/10.1016/j.jbankfin.2004.06.015

50. Berger AN, Hancock D, Humphrey DB (1993) Bank efficiency derived from the profit function. J Bank Finance 17(2-3):317-347. https://doi.org/10. 1016/0378-4266(93)90035-C

51. Seiford LM, Zhu J (1999) Profitability and marketability of the Top 55 U.S. Commercial Banks. Manag Sci 45(9):1270-1288. https://doi.org/10.1287/ mnsc.45.9.1270

52. Berger AN, Hasan I, Zhou M (2009) Bank ownership and efficiency in China: what will happen in the world's largest nation? J Bank Finance 33(1):113-130. https://doi.org/10.1016/j.jbankfin.2007.05.016

53. Aebi V, Sabato G, Schmid M (2012) Risk management, corporate governance, and bank performance in the financial crisis. J Bank Finance 36(12):3213-3226. https://doi.org/10.1016/j.jbankfin.2011.10.020

54. Fahlenbrach R, Stulz RM (2011) Bank CEO incentives and the credit crisis. J Financ Econ 99(1):11-26. https://doi.org/10.1016/j.fineco.2010.08.010

55. Beltratti A, Stulz RM (2012) The credit crisis around the globe: why did some banks perform better? J Financ Econ 105(1):1-17. https://doi.org/ 10.1016/j.jfineco.2011.12.005

56. Berger AN, Bouwman CHS (2013) How does capital affect bank performance during financial crisesa. J Financ Econ 109(1):146-176. https://doi. org/10.1016/j.jineco.2013.02.008

57. Santana A (2020) The relationship between financial development and economic growth in Latin American countries: the role of banking crises and financial liberalization. Glob Econ J 20(04):1-26. https://doi.org/10. 1142/S2194565920500232

58. Kamarudin F, Sufian F, Loong FW, Anwar NAM (2017) Assessing the domestic and foreign Islamic banks efficiency: insights from selected Southeast Asian countries. Future Bus J 3(1):33-46. https://doi.org/10. 1016/j.fbj.2017.01.005

59. Chowdhury MAM, Haron R, Sulistyowati MIK, Masud AI MA (2020) The efficiency of commercial banks in Indonesia. Int J Econ Policy Emerg Econ 1(1):1-23. https://doi.org/10.1504/JEPEE.2020.10034525

60. Xu H (2016) Financial intermediation and economic growth in China: new evidence from panel data. Emerg Mark Financ Trade 52(3):724-732. https://doi.org/10.1080/1540496X.2016.1116278

61. Zeqiraj V, Hammoudeh S, Iskenderoglu O, Tiwari AK (2020) Banking sector performance and economic growth: evidence from Southeast European countries. Post-Communist Econ 32(2):267-284. https://doi.org/10.1080/ 14631377.2019.1640988

62. Moudud-UI-Huq S (2020) Does bank competition matter for performance and risk-taking? Empirical evidence from BRICS countries. Int J Emerg Mark 16(3):409-447. https://doi.org/10.1108/JJOEM-03-2019-0197

63. Berger AN, DeYoung R (1997) Problem loans and cost efficiency in commercial banks. J Bank Finance 21:849-870

64. Ryu D, Yu J (2021) Nonlinear effect of subordinated debt changes on bank performance. Finance Res Lett 38(January 2020):101496. https://doi. org/10.1016/j.frl.2020.101496 
65. Tam OK, Liang HY, Chen SH, Liu B (2021) Do valued independent directors matter to commercial bank performance? Int Rev Econ Finance 71(April 2020):1-20. https://doi.org/10.1016/j.iref.2020.06.005

66. Lehmann-Hasemeyer S, Wahl F (2021) The German bank-growth nexus revisited: savings banks and economic growth in Prussia. Econ History Rev 74(1):204-222. https://doi.org/10.1111/ehr.13030

67. Haini H (2021) Examining the nonlinear impact of the banking sector on economic growth: evidence from China's Provinces. J Chin Econ Bus Stud. https://doi.org/10.1080/14765284.2021.1943193

68. Xi J, Kraus S, Filser M, Kellermanns FW (2015) Mapping the field of family business research: past trends and future directions. Int Entrep Manag J 11(1):113-132. https://doi.org/10.1007/s11365-013-0286-z

69. Gaies B, Nabi M (2021) Banking crises and economic growth in developing countries: why privileging foreign direct investment over external debt? Bull Econ Res 73:736-761. https://doi.org/10.1111/boer.12271

70. Isnurhadi I, Adam M, Sulastri S, Andriana I, Muizzuddin M (2021) Bank capital, efficiency and risk: evidence from Islamic banks. J Asian Finance Econ Bus 8(1):841-850. https://doi.org/10.13106/jafeb.2021.vol8.no1.841

71. Kchikeche A, Khallouk O (2021) On the nexus between economic growth and bank-based financial development: evidence from Morocco. Middle East Dev J 13:245-264. https://doi.org/10.1080/17938120.2021.1930830

72. Li R, Li L, Zou P (2021) Credit risk shocks and banking efficiency: a study based on a bootstrap-DEA model with nonperforming loans as bad output. J Econ Stud 48(1):1-19. https://doi.org/10.1108/JES-08-2019-0395

73. Stewart R, Chowdhury M (2021) Banking sector distress and economic growth resilience: asymmetric effects. J Econ Asymmetries 24:e00218. https://doi.org/10.1016/j.jeca.2021.e00218

\section{Publisher's Note}

Springer Nature remains neutral with regard to jurisdictional claims in published maps and institutional affiliations.

\section{Submit your manuscript to a SpringerOpen ${ }^{\circ}$ journal and benefit from:}

- Convenient online submission

- Rigorous peer review

- Open access: articles freely available online

- High visibility within the field

- Retaining the copyright to your article

Submit your next manuscript at $\boldsymbol{\nabla}$ springeropen.com 